\title{
Designing a Pre-Service ELT Methods Course and Use of Case Method Analysis
}

\author{
Fumi Takegami \\ Faculty of Letters, Department of English Language and Literature \\ Prefectural University of Kumamoto \\ 3-1-100, Tsukide, Higashi-ku, Kumamoto, 862-8502, Japan \\ Tel: 81-96-383-2929Ｅ-mail: takegami@ @u-kumamoto.ac.jp
}

Received: March 30, 2020

Accepted: April 30, 2020

Published: May 31, 2020

doi:10.5296/gjes.v6i1.16773

URL: https://doi.org/10.5296/gjes.v6i1.16773

\begin{abstract}
This paper aims to show the design and implementation of an English Language Teaching (ELT) methods course based on five conditions. Four were related to research on ELT methods: There is no single best method; there are numerous methods that exist in the literature; the claim that ELT is in a post-method era, and teachers need to be better informed of learning theories to further understand teaching methods. The fifth condition was based on a pedagogic rational that implementation of course materials must be socially mediated, through discussion and critical analysis. The paper outlines a theory to method to practice syllabus design of a 15-week, 90-minute course to 14 pre-service English teacher education majors at a university in Japan. Collaborative case method analysis was used to give students opportunities to analyze real classroom events that go beyond lectures and contents in the textbook. Students discussed the case in collaboration, and tried to apply what they learned in the course in their analysis. Results of a two-part questionnaire to learn students' views on course content and use of case method analysis were given. Outcomes showed students felt they could make connections to learning theories and methods, and that case method analysis was beneficial in their teacher learning. The research contributes to designing an ELT methods syllabus and using case study method analysis. Although the outcomes from the course of 14 students were positive, further research in using the design of the course is encouraged to strengthen the findings.
\end{abstract}

Keywords: Case method analysis, ELT methods, Pedagogic rational, Post-method era, Syllabus design, Teacher learning 


\section{Introduction}

Upon entering a new position, I was asked to design and teach an English Language Teaching (ELT) methods course for $3^{\text {rd }}$ year pre-service teachers at university in Japan. The course was a requirement for English language teacher majors. The first step was to consider existing professional knowledge that underpinned five conditions. The first four were related to research on methods in ELT as follows: 1) ELT methods research has long demonstrated that there is no singular best method (Allwright, 1988; Prabhu, 1990); 2) there are numerous ELT methods that exist, at least in the literature (e.g., Richards \& Rodgers, 2001, Larsen-Freeman \& Anderspm, 2011); 3) the position that language teaching is in a post-method era (Kumaradivelu, 2006), which claims that ELT methods as formulated in the literature for all practical concerns, are deficient in meeting the instructional demands of teaching and 4) to understand methods, pre-service teachers need to be better informed of learning theories (Stern, 1990; Widdowson, 1992).

The fifth condition was based on a pedagogical rationale that course materials should be socially mediated through critical and dialogical analysis so that students would be able to draw connections between theory and practice. This view was underpinned by both my personal pedagogical conceptualizations coming from over three decades of practical experience teaching in secondary education, and professional knowledge gained in postgraduate study. The latter brought about two theoretical perspectives on learning. One is to recognize the importance of the social nature of language as a tool to stimulate cognitive activity, and therefore learning is a socially mediated collaborative process (Vygotsky, 1978); the other is reflected in the canon of critical pedagogy that through problem solving education, students become active agents developing critical thinking skills that empower them to take control of their learning. They "come to see the world not as a static reality, but as reality in process, in transformation" (Freire, 1970, p. 71). In support of these views that informed my teaching approach, case method analysis in teacher education was selected as an appropriate framework to have students critically engage with the materials in collaboration (Levin, 1995).

The above depicts the context that surrounded the design of an ELT methods course. The aim of the study is to promote the proliferation of pedagogical research to better inform pre-service teacher development. The following research question to guide this study was as follows:

What is the most effective way to design an ELT methods course in the current language teaching environment, where there is (a) no best method, (b) numerous ELT methods, (c) claims of being in a post-method condition, and (d) the need to link theory with methods?

To address the research inquiry above, first, the five fundamental issues that led to the design of the ELT methods course are further explained. Next, the syllabus of the course is outlined followed by a discussion of what case method analysis is and why it is appropriate as pedagogical framework for this study. Data from this study focused on the syllabus design and course content up to case method analysis activity. Results of a questionnaire to evaluate 
students' perceptions of course materials are analyzed. Finally, implications of the study are given.

\subsection{There Is No Singular Best ELT Method}

A view that had stimulated researchers was the belief that the answer to improve teaching was in the methodology. For example, Charles Fries (1945), a structural linguist, believed that a systematized, structure-based method that provided a recipe that teachers could follow in a step by step manner (making it teacher proof), regardless of how weak the pedagogical skills of the teacher were, would be best. Consequently, experiments to prove a best method were conducted. However, these attempts failed. A major reason was that they could not control the teacher variable to validate if teachers were purely teaching from the method being tested (Long, 1991). Although this result meant looking for a best method to be widely adopted in language teaching no longer made sense, it did shed light on the importance of research to focus more on the teacher. In retrospect, Allwright (1988) observed,

The time was ripe for an alternative approach to classroom language learning research, and approach that would no longer see the language teaching world in terms of major rival 'methods' and one that would be more respectful of the complexities of the language teacher's task (p. 10).

Nonetheless, the failure of research to find the best method did not end the search for language teaching methods. This is evident in the many teaching methods that continued to emerge in the latter part of the $20^{\text {th }}$ century.

\subsection{There Are Myriad ELT Methods That Exist, at Least in the Literature}

Richards and Rodgers (2001) detail 15 methods in their book (they also acknowledge the post-method era) and Larsen-Freeman and Anderson (2011) offer ten along with three others that are not fully comprehensive, but nevertheless "....reflect interesting and enduring methodological practices" (p.181). Moreover, the authors of both books include a caveat that their intention is not to prescribe or expect that teachers would solely teach a method, but to outline the methods as a reference guide to make teachers aware of the existing methods for them to do what they want according to their circumstances. A noteworthy feature of Richards and Rodgers book is their attempt to bring coherence to the methods they discuss by adapting a theory to practice hierarchal framework. The importance of a theory to method to practice framework informs teachers why they are doing what they are doing when they apply aspects of the methods. The significance of being pedagogically informed is addressed in the next two sections.

\subsection{The Position That Language Teaching Is in a Post-Method Era}

Kumaradivelu (2006) wrote that ELT is in a post method era. He suggested previous methods were built on a transmission model of education approach that inundated teachers with a plethora of prescribed methods, which ignored the complex realities teachers were facing. Prahbu (1990) argued about the difficulty to associate a prescribed method with teachers because they will carry out a set of procedures or methods that they feel will plausibly work 
for their teaching environments. Kumaradivelu added that methods cannot address the particularities that teaches face in their classrooms, and therefore teachers "find such a methods-based teacher education woefully inadequate to meet the challenges of the practice of everyday teaching" (p.169). As a result, he pointed out that teachers resort to creating their own personal method derived from a disarray of various methods and techniques, which becomes an "eclectic method" (p. 169). It may seem that eclecticism in teaching is fine because the teacher has many tools at her side. However, when eclectic teaching is applied without any cohering principles or theories, it loses credibility. Widdowson (1990) wrote, "If by eclecticism is meant the random and expedient use of whatever technique comes most readily to hand, then it has no merit whatever" (p. 50). In short, the uninformed eclectic method means that although teachers would know what technique or method they are applying at the superficial level, they would fail to understand at the deeper theoretical level why they are doing what they are doing. Without principled or theoretical coherence, "the choice is left to the individual's intuitive judgement and is, therefore, too broad or vague to be satisfactory as a theory" (Stern, 1992, p. 11). The preceding comments demonstrate the need for teachers to be informed practitioners: not only informed by their personal theories of teaching underpinned by classroom experiences, but also professional theoretical knowledge rooted in the field of pedagogy. It is the latter case that can be addressed in teacher development courses in university.

\subsection{Pre-Service Teachers Need to Be Better Informed of Learning Theories}

In the present state of language teaching, knowledge of learning theories that underpin teaching methods is necessary. Prabhu (1990) wrote about the importance of theory "as set of ideas or principles that cohere to make up a conceptual model, or theory... for making sense of complex phenomena and conveying that sense to one another" (p. 166). Learning theories provide coherence to teaching methods. In a praxis learning model, the cycle of learning is cyclical as theory informs practice and practice informs theory. For pre-service teachers, having an understanding of principles associated with theories provides a conceptual framework to better understand the foundations of teaching methods in action. If methods represent a set of procedures of 'what' teachers do, theories are the propositions for 'why' they do them in terms of learner acquisition. Based on this premise, the syllabus design of the course included the introduction of two major learning theories that are explained in section 2.1 further below.

\subsection{Pedagogical Conceptualizations in Practice Informed by Theoretical Perspectives}

A study of methods is also a means of socialization into professional thinking and discourse that language teachers require in order to 'rename their experience,' to participate in their profession, and to learn throughout their professional lives (Larsen-Freeman \& Anderson, 2011, p. xi).

Conceptualizations for the design of the syllabus emerged from two domains. First, they were grounded in my personal pedagogical knowledge based on secondary school classroom teaching experience. However, as Freeman (1996) pointed out personal experiences based primarily on localized knowledge of teaching can become stagnant. Freeman argued that 
what is often lacking in teacher development is a richer secondary discourse domain underpinned by professional pedagogical knowledge. Through encountering professional knowledge and discussing it with other teachers within a community of practice, teachers can better internalize the information. In other words, through professional discourse, teachers are able to reconceptualize their instruction, which better informs their teaching. Freeman posited that opportunities to articulate professional knowledge in practice should be a major role of postgraduate teacher programs. In my own case (Takegami, 2015), professional knowledge was enhanced during postgraduate study through participating in discussions about pedagogical concepts in practice. This led to renaming my teaching experiences and reconceptualizations of teaching that could be used to better inform how I would design the course.

\section{Theoretical Design of the Course}

I decided that the course would go from learning theory to complementary teaching methods to practical analysis. The latter would include case method for analysis and student participation in simulated teaching activities.

\subsection{Learning Theories and Complementary Teaching Methods}

Behaviorism and social constructivism represented two major learning theories that were covered in the course. In the theory of behaviorism, learning is externally driven through stimulus-response and reinforcement. In the classroom, the external view of learning is manifested in the transmission model of teaching. Course content requires a teacher-centered approach, in which the teacher models ongoing repetition of material in a sequential step by step manner that students repeat. Through continuous drilling of content, positive reinforcement leads to learning. On the other hand, in social constructivism, learning is a cognitive process and therefore internally driven. In the classroom, the "social" aspect of constructivism emphasizes the collaborative nature of learning and a student-centered approach. Through peer interaction in pair or group activities, students participate in socially constructing knowledge during collaboration. Then, the socially mediated learning process is internalized and stimulates cognitive activity in the individual to increase learning.

Introducing these two distinctively different theories offered the students a broad view of learning principles that underpin many teaching methods. Although other methods related to the two theories were briefly covered in the course (see section 2.4), a binary choice was initially made to focus on audiolingual method (ALM) and communicative language teaching (CLT) methods because they are clearly two complementary teaching approaches that are linked to the learning theories. Unlike ALM, which did arise from behaviorism, CLT emerged as a common-sense method that drew on practical and functional ways that we use language to communicate without being linked to a learning theory. However, Williams and Burden (1997) have argued in their work that social constructivism goes a long way into providing a theoretical underpinning for communicative approaches. Thus, these two methods would encapsulate a variety of methods that are either tied to structural, functional and interactional views of learning a language. 


\subsection{Communicative Competence}

To demonstrate the integration of course content, the communicative competence model was included in the course design. The concept first appeared in Hymes (1972) in response to Chomsky's (1965) work on linguistic competence. Hymes felt Chomsky left out a very important social dimension regarding language competence. Furthering Hymes, Canale and Swain (1980) introduced the communicative competence model in four competence areas that combine both Chomsky's linguistic dimension (structure, discourse) and Hymes' social dimension (sociolinguistic, strategic). Linguistic focuses on knowledge about the language (grammar, phonology, sentence formation); Social emphasized the functional and interactive aspects of communication (appropriate use in social situations, strategies to apply when communication breaks down). By introducing the model to the students, they could see applications of behaviorism and ALM that focus on linguistic knowledge, and social constructivism and CLT that are applicable toward developing learners' abilities to use the language for communication.

\subsection{Case Method}

An important element of the course was to ensure that students would experience opportunities to put theories into practice and to reflect on them critically using case method analysis. Case method is made up of real situations that occurred in professional practice. The cases provide opportunities for participants to encounter complex situations that would require critical thinking skills to solve. In the case of teaching, a classroom situation is given providing background information and then a description of a dilemma or problem that has emerged. There are no procedural steps or solutions given to solve the problem. Participants are afforded the opportunities to put what they have learned in theory into practice. Thus, course content becomes the analytical tools for the students to resolve situations. Discussion among participants of a case is highly beneficial in helping the participants determine solutions (Levin, 1995, Takegami, 2020). One favorable aspect of case method for pre-service teachers is that cases provide models of teaching taking place in actual classes. Examples of teachers in action offer good examples of prescriptive teaching techniques underpinned by learning theories and methods that they studied in a course.

\subsection{Course Syllabus}

The course content was planned for one semester, totaling 15, 90-minute classes. In the first session, the plan was to activate students' background knowledge about English language teaching and to provide an historical background of shifts in approaches to ELT methods. Then, the learning theories were introduced. This was followed by the complementary ELT methods. To introduce this latter part, students used the coursebook, Techniques \& Principles in Language Teaching 3rd edition (Larsen-Freeman \& Anderson, 2011). The book surveys ten ELT methods and three sub-methods (see section 1.2); seven of those were selected with two of them being ALM and CLT. The seven methods were combined into three theoretical views of language listed as structural, functional and interactional that inform contemporary methods (Richards \& Rodgers, 2001). The structural view emphasizes the importance of phonological units, sequential order of grammatical units, grammatical structures and vocabulary found in 
grammar-translation (GT), Total Physical Response (TPR) and ALM. The functional and interactional views emphasize that language is based on the practical purpose to convey information and is socially mediated as a tool to express and stimulate cognitive activity. The two can be merged and established in Content-based Instruction (CBI), Task-based learning teaching (TBLT), Cooperative language learning (CLL), Content and language integrated learning (CLIL) and CLT. Although the seven methods were introduced in the course, ALM and CLT were focused on to draw the distinction between the three theoretical views that are underpinned by behaviorism (structural) and social constructivism (functional/interactional).

The rationale for integrating methods when appropriate was addressed in the communicative competence model. After studying theories, methods and competence model, the course shifted to practice. Students were introduced to case method analysis. They were given a real classroom example from an experience I had working with a high school English teacher who wanted help in teacher development. He noticed that the students were passive and looked bored. He wanted to find ways to make his class more interactive and focus less on grammar translation-type activities. The pre-service students were told to analyze the case from both the teacher's and students' perspectives. The criteria for analyzing the case was to make suggestions for what the teacher could do based on theories and methods studied in the course. Afterward, three sessions designed for practical applications of course content were conducted in simulated team-teaching lessons. (Data from the simulated teaching practice are presented in a future study.) The course concluded with a questionnaire to receive feedback for the course.

Session 1: Warm up activity: What do you know about English education?

Historical context of ELT methods, overview of course content

Session 2: Introduction of learning theories: Behaviorism

Session 3: Audiolingualism

Session 4: Teaching methods attached to the structural view (GT, TPR)

Session 5: Introduction of learning theories: Social Constructivism

Session 6: Communicative Language Teaching

Sessions 7,8: Teaching methods attached to the functional/interactional view (CBI, TBLT,

CLIL, CLL)

Session 9: Communicative Competence Model

Session 10: Case Method example for critical analysis from teacher's point of view

Session 11: Case Method example for critical analysis from students' point of view

Session 12: Preparation for focused mini-lesson teaching team activity (Design and teach an activity that is supported by a learning theory and related teaching method)

Sessions 13,14: Team teaching focused mini-lesson simulated teaching practice

Session 15: Review and evaluation of course content

Figure 1. Course Syllabus Divided into 15 Classes Covering One Semester. 


\section{Macrothink}

\section{Method}

The study was designed to take an exploratory and interpretive approach to gather information about the course. Fourteen students (the total number who took the course) were given a questionnaire to learn their overall perceptions about the syllabus.

\subsection{Data Collection and Analysis}

In the final class, a two-part questionnaire was given to the students to receive feedback using a 5-point Likert scale, and open questions to generate more data, respectively. Students were asked to respond on a scale ranging from a perceived high degree to low degree of understanding. In addition, they were asked to qualitatively explain their answers. In the first part, the focus was to gain insights into students' perceptions to the degree in which they could understand the learning theories and complementary teaching methods. Figure 2 shows the results.

Q 1. Could you understand the difference between behaviorism and social constructivism?

Q 2. Could you understand the relationship between behaviorism and audiolingualism?

Q 3. Could you understand the relationship between social constructivism and CLT?

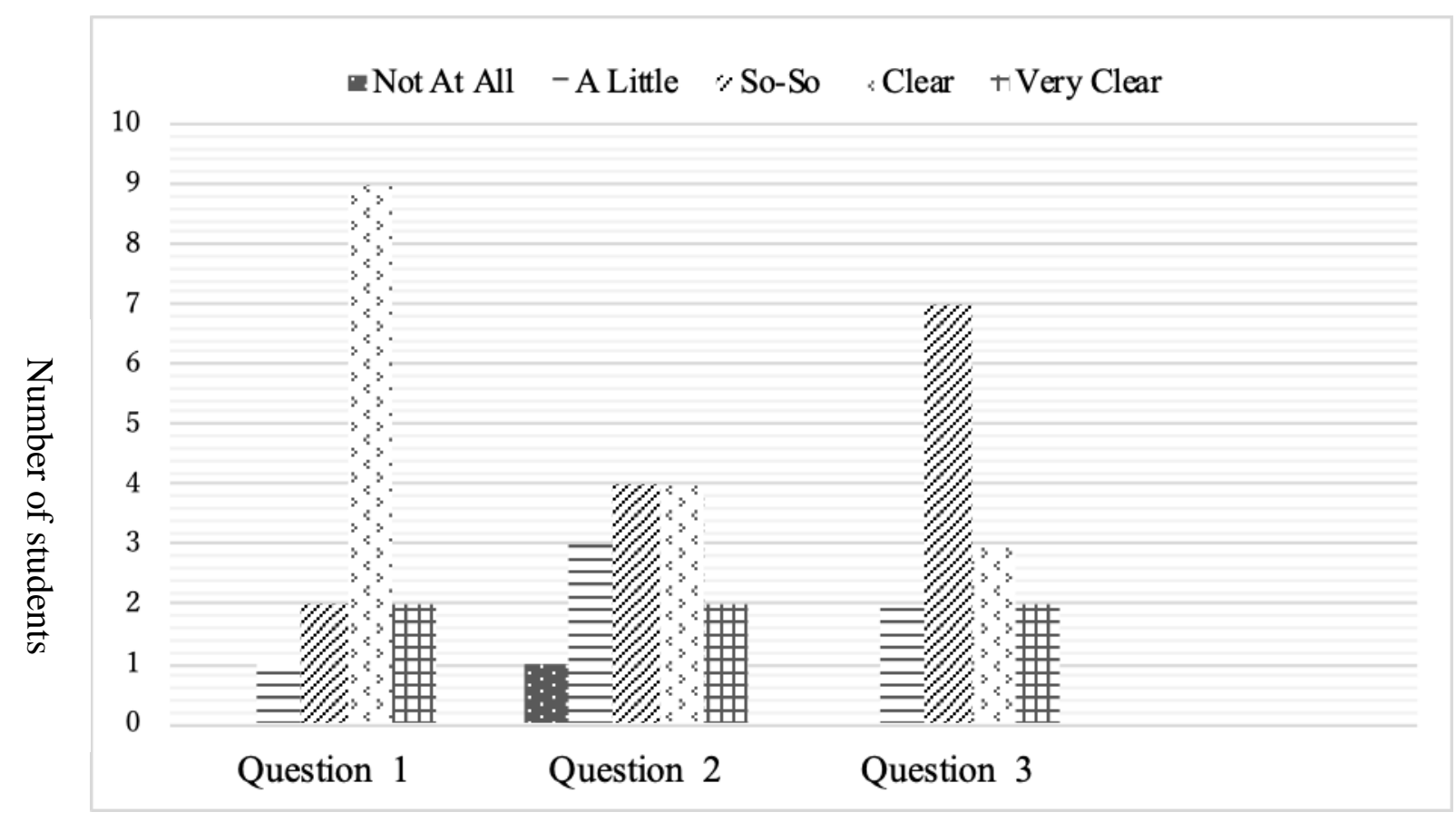

Figure 2. Results of Students' Perceptions on Understanding the Learning Theories and Corresponding Teaching Methods Ranging from (1) Not at all, (2) A little, (3) So-so, (4) Clear, (5) Very clear

In the first question, most respondents felt they understood the differences between the two theories. A sampling of student comments with corresponding ranking scale are presented: 


\section{Macrothink}

Global Journal of Educational Studies

ISSN 2377-3936

2020, Vol. 6, No. 1

- Comments on understanding differences between behaviorism and social constructivism.

$5 \sim$ Behaviorism is based on the idea that people learn things through getting into learning habit of learning through repetition and imitation and so on. On the other hand, social constructivism focuses on more socially mediated learning such as active learning.

4 - We have been taught English based on behaviorism when we were students. Social constructivism is the way we [students] could get the answer through negotiating and interacting with other students in the class.

3 I think I see what the two [behaviorism and social constructivism] mean. However, still I cannot make connection to the theory and practice.

$2 \sim$ I don't think I can understand the differences between the behaviorism and social constructivism.

In the following questions, when asked if they could understand the links between theories and complementary methods, there was a bit less certainty (Figure 2.) although comments were favorable as shown below:

- Comments on understanding the links between behaviorism and audiolingualism.

$5 \sim$ Audiolingualism is a teaching approach based on behaviorism, and students can learn the second language through listening repeatedly and practice its structure until they remember the second language.

4 I think behaviorism and audiolingualism approach are old style of learning, where languages are simply learned through repetition. Also, behaviorism is connected to grammar-translation because grammar translation is structure-based approach.

3 Audiolingualism is a teaching approach focusing on listening and speaking, and also it is based on the theory of behaviorism.

$2 \sim$ I am not sure about how they connect to each other though I understand the two words.

- Comments on understanding differences between social constructivism and CLT.

5 In CLT, teachers need to give students problem solving activities in their language classes and they [students] should find the way to solve them. It can be called social constructivism.

4 In CLT, students can be active in the language learning classroom since it focuses on more communication. So, it is strongly related to social constructivism.

3 I think CLT includes the concept of communicative competence, so we can improve communicative competence more in social constructivism.

$2 \sim$ I am not sure about how they connect to each other though I understand the two 
words.

The next set of questions focused on how much the students felt they benefited by studying with case method (Figure 3.). The first two questions were aimed at how much the respondents could analyze the case from the view of the teacher (Q4) and then from the students' perspective (Q5). Data are shown in Figure 3.

Q 4. Was it helpful to look at a real teaching case to analyze from the teacher's view?

Q 5. Was it helpful to look at a real teaching case to analyze from the students' view?

Q 6. Was it helpful to discuss a real teaching case to analyze with your classmates?

Q 7. When finding a solution to the case, did the content of this course help you?

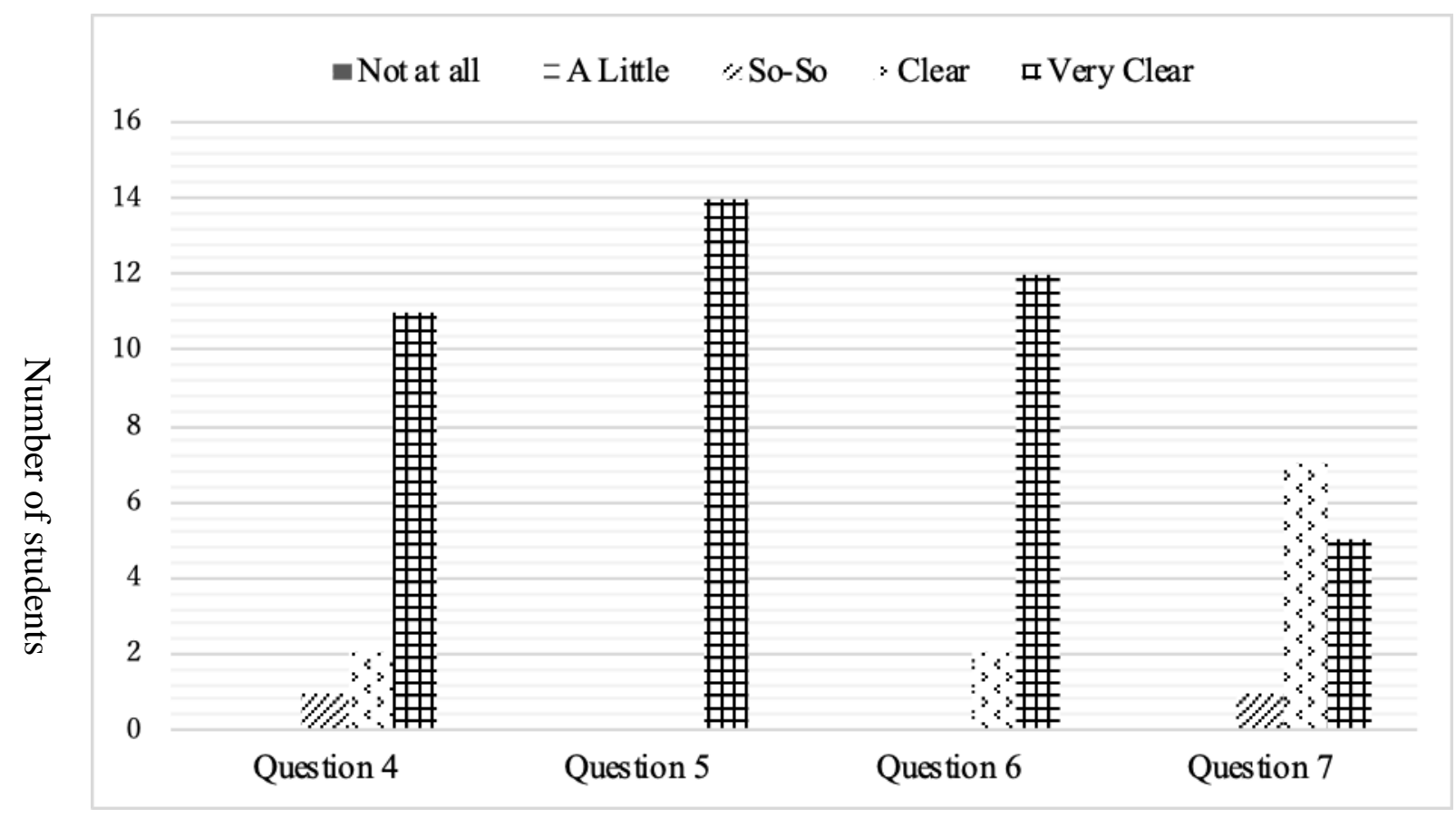

Figure 3. Perspectives on the Use of Case Method Ranging from (1) Not at all, (2) A little, (3) So-so, (4) Clear, (5) Very clear

The sampling of responses according to ranking scale show the students felt they overwhelmingly benefited. In case method, role play, putting oneself in the place of the subjects in a situation, is essential. The results of questions four (teacher's role) and five (students' role) support the long-standing constructive uses of role play in education as the responses were very favorable toward viewing the situation from both the teacher's and students' perspectives.

- Comments expressing helpfulness of viewing case from teacher's role. 


\section{Macrothink}

Global Journal of Educational Studies

ISSN 2377-3936

2020, Vol. 6, No. 1

5 I could see teaching from objective perspective. This allowed me to analyze teaching approach from teacher's view.

I could see clearly that some students did not respond to the activity or did not understand, which stimulated me to consider what we should change.

I don't have any experience as a teacher. But I could analyze teaching from various perspectives since I reflected what teachers did in my school days to what we need to do.

It was helpful because I could find out the problems in this teaching approach.

$4 \sim$ I found that it is very difficult to teach what teachers know to students from the beginning.

3 Neither. Since this class is based on student-centered activity and teacher and students seemingly interact well, I cannot say whether analyzing it from teacher's view is helpful or not.

- Comments expressing helpfulness of viewing case from students' role.

$5 \sim$ To look at real teaching case from students' view was very helpful since I could see which part of the activities is helpful and need to be changed or how students could feel during the class.

$\sim$ By playing a role of students, I found that students could cooperate and each other and inspire each other.

I could see clearly what was difficult for students by thinking about the problem in this approach.

I realized group work made me relax in the class. Mistake is OK. But on the other hand, I wondered what teacher was doing?? Just wandering in the class?

r thought we need a student who takes a leadership in the activity.

In question six (Figure 3.), the social and dialogic gains from having participants engage in discussions were shown. By having students discuss a case dealing with real teaching issues, they were given chances to socially construct knowledge through sharing views, which then led to building individual knowledge. In turn, teacher thinking, and therefore teacher learning, was further developed (Levin, 1995; Freeman, 1996). A sampling of comments is shown below:

- Responses about discussing the case with classmates.

$5 \sim$ We found the problems and possible solutions while discussing with classmates, which could not come up to my mind.

$\sim$ By sharing opinions, I could deepen my understanding and find out problems of the case clearly. 


\section{Macrothink}

Global Journal of Educational Studies

ISSN 2377-3936

2020, Vol. 6, No. 1

I could feed back what I thought in the group though discussion and see how to improve the class.

I could get various point of view for teaching.

I could get the different point of teaching and problem and solutions that I could not do by myself.

$4 \sim$ Probably I could get more opinion from others.

In question seven (Figure 3.), the students' comments were favorable overall showing they could draw connections to what they studied in theory to applying it in practice to analyze the case.

- Responses about applying course materials to case analysis.

$5 \sim$ Yes. I could consider a solution to the case by using prior knowledge learned in the ELT method course.

I could mix the information I got from approaches for the solution.

4 I could gain the basic knowledge to find the solution of the case in this course.

The activity of trying to find a solution could make me to reconsider what we have learned in the course.

The content in the course must be one of avenue to solve the problem, but don't think there is not a correct answer all the time in the method.

3 I could not make connection between the content of this course and solution for this case. Is it because I am too much familiar with audiolingualism?

The analysis of data indicate that the course was seemingly effective. Responses mostly indicated students felt they could see the differences between the two theories, and the theoretical connections to the methods.

\section{Discussion}

One faces a broad landscape when developing an ELT methods course. It is a daunting challenge to design an ELT methods course in a field where there is no best method, or either too many methods or no real existing method because ELT is in a post-method era. Faced with these realities, the syllabus was designed to take a manageable theory to method to practice approach. Course content was portrayed in a manner that allowed students to think about teaching in terms of why teachers do what they do in their instruction. Thus, principles of selected learning theories (why) and complementary teaching methods (what) were introduced. The results of the questionnaire and students' comments suggest that the ELT methods course was effective. Students felt they could draw distinctions between the two learning theories and their corresponding methods. For example, as students were given the option for free comments in the questionnaire, one student reflected on the effectiveness of the course, 
I learned that there are lots of teaching methods and each method has learning theory. I would like to use some teaching methods in the pre-service teaching training next year. Also, I learned that we have different perspectives toward teaching by analyzing the case in the class collaboratively.

The student also alluded to the benefits of using case method analysis of a case from an actual classroom. The results of the questionnaire and comments showed students highly felt it was beneficial for their teacher development to analyze a real teaching situation. Case method analysis of real teaching situations provides a link between theory and practice. It brings reality to teaching that cannot be found in lectures or learning from the textbook. Moreover, the data show that having students discuss a case in collaboration was very fruitful. Students felt through discussions in collaborations with other students that their learning improved. Thus, an implication is that case method analysis would be a resourceful pedagogical framework to use in a methods course.

Although the triangulated results of the questionnaire, and supporting comments to determine the effectiveness of the syllabus for an ELT methods course with case method analysis were positive, there are some limitations. Data came from 14 students who took the course, but substantiation of the claimed benefits needs to be strengthened with further data from a higher number of participants in future research. Nonetheless, the syllabus design and the use of case method had a positive effect on the learning potential of the students, as shown in several comments below:

I need to remember that there are theories and principles and methods for the future when I become an English teacher.

I would like to use the knowledge from this course for the teacher license training.

I could understand that there are various teaching methods and approaches and principles.

I found that it is time to change our teaching approaches to improve students' "communicative competence".

The flow of the syllabus design and the results from students indicate that the course was effective. Students could gain professional knowledge that teachers should have when they enter the field of teaching. More than arguing for a best method or that methods do not exist in the classroom, introducing pre-service students to the concept of methods and underpinning theories at least endows them with the professional discourse that can lead to better conceptualizations of teaching when they become practitioners. As Bell (2007) wrote,

A knowledge of methods is equated with a set of options, which empower teachers to respond meaningful to particular classroom contexts. In this way, knowledge of methods is seen as crucial to teacher growth (p. 141-2).

The content and design of the course could reach its goal. Students felt they increased their learning potential to articulate and conceptualize learning theories and methods that would better inform their teacher development. Based on the results of the study, the syllabus design 
and use of case method analysis may be transferable to other similar contexts in foreign language programs that offer an ELT methods course.

\section{Conclusion}

The goal of the course was to present information in a coherent way to better prepare pre-service students as future professionals, who are entering a teaching and learning environment in which the concept of teaching methods is fluid and ever changing. The outline of the syllabus in 15 weeks encapsulated the course approach. After detailing the rationale for the syllabus design based on the four existing realities that surround ELT methods research, case method analysis was implemented as the pedagogical approach to have students engage with the course content. Questionnaire results and students' comments indicated the effectiveness of the course.

The field of teaching and learning is an ever dynamic and constantly changing landscape. It is fertile ground for transformation. An ELT methods course plants the seeds for professional growth. What the students learn in the course, prepares them to be future teachers, and to find better ways of teaching. This can be seen in the comment from a student at the end of the course,

Many teaching methods have emerged along with the change of the time and needs from the time. So, we should find better teaching approaches for the world of the $21^{\text {st }}$ century.

This should be the on the ongoing aim of teacher educators as well.

\section{References}

Allwright, D. (1988). Observation in the Language Classroom. New York City, NY: Longman.

Bell, D. (2007). Do teachers think that methods are dead? ELT Journal, 61(2), 135-43. https://doi.org/10.1093/elt/ccm006

Canale, M., \& Swain, M. (1980). Theoretical bases of communicative approaches to second language teaching and testing. Applied Linguistics, 1(1) 1-47, https://doi:10.1093/applin/i.1.1.

Chomsky, N. (1965). Aspects of the Theory of Syntax. Cambridge, MA: M.I.T. Press.

Freeman, D. (1996). Renaming experience/reconstructing practice: Developing new understanding of teaching. In D. Freeman, \& J. C. Richards (Eds.), Teacher learning in language teaching (pp. 221-241). Cambridge, England: Cambridge University Press.

Freire, P. (1993). Pedagogy of the Oppressed. New York City, NY: Continuum.

Fries, C. (1945). Teaching and Learning English as a Foreign Language. Ann Arbor, MI: University of Michigan Press.

Hymes, D. H. (1972). On communicative competence. In J.B. Pride \& J. Holmes (Eds.),

Sociolinguistics (pp. 269-293). London, England: Penguin. https://doi.org/10.1075/itl.22.06van 


\section{Macrothink}

Global Journal of Educational Studies

ISSN 2377-3936

2020, Vol. 6, No. 1

Kumaravadivelu, B. (2006). Understanding Language Teaching: From Method to Postmethod. Mahwah, New Jersey, Lawrence Erlbaum Associates.

Larsen-Freeman, D., \& Anderson, M. (2011). Techniques \& Principles in Language Teaching (3rd ed.). New York, NY: Oxford University Press.

Levin, B. B. (1995). Using the case method in teacher education: The role of discussion and experience in teachers' thinking about cases. Teaching and Teacher Education, 11, 63-79. https://doi.org/10.1016/0742-051x(94)00013-v

Long, M. (1991). Focus on Form: A Design Feature in Language Teaching Methodology. In K. De Bot, R. Ginsberg, \& C. Kramsch (Eds.), Foreign Language Research in Cross-Cultural Perspectives (pp. 39-52). Amsterdam, Netherlands: John Benjamins. https://doi.org/10.1075/sibil.2.07lon

Prabhu, N. S. (1990). There Is No Best Method-Why? TESOL Quarterly, 24(2), 161-176. https://doi.org/10.2307/3586897

Richards, J. C., \& Rodgers, T. S. (2001). Approaches and method in language teaching. Cambridge, England: Cambridge University Press.

Stern, H. H. (1992). Issues and options in language teaching. Oxford, England: Oxford University Press.

Takegami, F. (2015). A Japanese teacher of English's conceptualizations of a lesson grounded in professional discourse to better inform practice. The Asian Journal of Applied Linguistics 2(3), 186-201. http://caes.hku.hk/ajal/index.php/ajal/article/ view/243.

Takegami, F. (2020). Making the Case for Case Method in Teacher Development: What? Why? How? Journal of The Faculty of Letters of Prefectural University of Kumamoto, 26(79), $37-48$.

Vygotsky, L. (1978). The mind in society. Cambridge, MA: Harvard University Press.

Widdowson, H. G. (1990). Aspects of language teaching. Oxford, England: Oxford University Press.

Williams, M., \& Burden, R. L. (1997). Psychology for language teachers: a social constructivist approach. Cambridge, England: Cambridge University Press.

\section{Copyright Disclaimer}

Copyright for this article is retained by the author(s), with first publication rights granted to the journal.

This is an open-access article distributed under the terms and conditions of the Creative Commons Attribution license (http://creativecommons.org/licenses/by/3.0/). 